Subscriber access provided by University of East Anglia Library

\title{
Article
}

\section{Hydrogeological controls on regional-scale indirect nitrous oxide (N2O) emission factors for rivers}

\author{
Richard James Cooper, Sarah Katrina Wexler, Christopher Adams, and Kevin M. Hiscock
}

Environ. Sci. Technol., Just Accepted Manuscript • DOI: 10.1021/acs.est.7b02135 • Publication Date (Web): 25 Aug 2017

Downloaded from http://pubs.acs.org on August 31, 2017

\section{Just Accepted}

"Just Accepted" manuscripts have been peer-reviewed and accepted for publication. They are posted online prior to technical editing, formatting for publication and author proofing. The American Chemical Society provides "Just Accepted" as a free service to the research community to expedite the dissemination of scientific material as soon as possible after acceptance. "Just Accepted" manuscripts appear in full in PDF format accompanied by an HTML abstract. "Just Accepted" manuscripts have been fully peer reviewed, but should not be considered the official version of record. They are accessible to all readers and citable by the Digital Object Identifier (DOI®). "Just Accepted" is an optional service offered to authors. Therefore, the "Just Accepted" Web site may not include all articles that will be published in the journal. After a manuscript is technically edited and formatted, it will be removed from the "Just Accepted" Web site and published as an ASAP article. Note that technical editing may introduce minor changes to the manuscript text and/or graphics which could affect content, and all legal disclaimers and ethical guidelines that apply to the journal pertain. ACS cannot be held responsible for errors or consequences arising from the use of information contained in these "Just Accepted" manuscripts. 


\section{Hydrogeological controls on regional-scale indirect nitrous oxide $2 \quad\left(\mathbf{N}_{2} \mathbf{O}\right)$ emission factors for rivers}

3 Richard J. Cooper*, Sarah K. Wexler, Christopher A. Adams, Kevin M. Hiscock

School of Environmental Sciences, University of East Anglia, Norwich Research Park, Norwich, NR4 7TJ, UK

*Correspondence: Richard.J.Cooper@uea.ac.uk

\section{Abstract}

Indirect nitrous oxide $\left(\mathrm{N}_{2} \mathrm{O}\right)$ emissions from rivers are currently derived using poorly constrained default IPCC emission factors $\left(\mathrm{EF}_{5 \mathrm{r}}\right)$ which yield unreliable flux estimates. Here, we demonstrate how hydrogeological conditions can be used to develop more refined regional-scale $\mathrm{EF}_{5 \mathrm{r}}$ estimates required for compiling accurate national greenhouse gas inventories. Focusing on three UK river catchments with contrasting bedrock and superficial geologies, $\mathrm{N}_{2} \mathrm{O}$ and nitrate $\left(\mathrm{NO}_{3}{ }^{-}\right)$concentrations were analyzed in 651 river water samples collected from 2011 to 2013. Unconfined Cretaceous Chalk bedrock regions yielded the highest median $\mathrm{N}_{2} \mathrm{O}-\mathrm{N}$ concentration $\left(3.0 \mu \mathrm{g} \mathrm{L}^{-1}\right), \mathrm{EF}_{5 \mathrm{r}}(0.00036)$ and $\mathrm{N}_{2} \mathrm{O}-\mathrm{N}$ flux $\left(10.8 \mathrm{~kg} \mathrm{ha}^{-1} \mathrm{a}^{-1}\right)$. Conversely, regions of bedrock confined by glacial deposits yielded significantly lower median $\mathrm{N}_{2} \mathrm{O}-\mathrm{N}$ concentration $\left(0.8 \mu \mathrm{g} \mathrm{L}^{-1}\right), \mathrm{EF}_{5 \mathrm{r}}(0.00016)$ and $\mathrm{N}_{2} \mathrm{O}-\mathrm{N}$ flux $(2.6 \mathrm{~kg}$ $\left.\mathrm{ha}^{-1} \mathrm{a}^{-1}\right)$, regardless of bedrock type. Bedrock permeability is an important control in regions where groundwater is unconfined, with a high $\mathrm{N}_{2} \mathrm{O}$ yield from high permeability Chalk contrasting with significantly lower median $\mathrm{N}_{2} \mathrm{O}-\mathrm{N}$ concentration $\left(0.7 \mu \mathrm{g} \mathrm{L}{ }^{-1}\right), \mathrm{EF}_{5 \mathrm{r}}(0.00020)$ and $\mathrm{N}_{2} \mathrm{O}-\mathrm{N}$ flux $(2.0 \mathrm{~kg}$ $\mathrm{ha}^{-1} \mathrm{a}^{-1}$ ) on lower permeability unconfined Jurassic mudstone. The evidence presented here demonstrates $\mathrm{EF}_{5 \mathrm{r}}$ can be differentiated by hydrogeological conditions and thus provide a valuable proxy for generating improved regional-scale $\mathrm{N}_{2} \mathrm{O}$ emission estimates.

Keywords: Denitrification; streams; climate change; greenhouse gas; IPCC; agriculture

\section{Introduction}

Nitrous oxide $\left(\mathrm{N}_{2} \mathrm{O}\right)$ is a powerful greenhouse gas with a global warming potential 265 times greater than carbon dioxide $\left(\mathrm{CO}_{2}\right)$ over a 100-year timescale. ${ }^{1}$ At a current atmospheric concentration of 329 ppb, ${ }^{2} \mathrm{~N}_{2} \mathrm{O}$ is the third most important well-mixed greenhouse gas behind $\mathrm{CO}_{2}$ and methane $\left(\mathrm{CH}_{4}\right)$, accounting for $6 \%$ of total anthropogenic radiative forcing $\left(0.17 \mathrm{~W} \mathrm{~m}^{-2}\right) \cdot{ }^{1,3} \mathrm{~N}_{2} \mathrm{O}$ is also the single most dominant stratospheric ozone $\left(\mathrm{O}_{3}\right)$ depleting substance emitted in the $21^{\text {st }}$ century through its 
31 have increased by $22 \%$ since $1750(270 \mathrm{ppb})^{5}$ and have been growing at an annual rate of $0.75 \mathrm{ppb}$ 32 since the late 1970 s. $^{3}$

$33 \mathrm{~N}_{2} \mathrm{O}$ is produced as a byproduct of bacterially-driven aerobic nitrification in soils, sediments and 34 waterbodies during the oxidation of ammonium $\left(\mathrm{NH}_{4}{ }^{+}\right)$to nitrate $\left(\mathrm{NO}_{3}{ }^{-}\right)$, by predominantly 35 autotrophic Nitrosomonas and Nitrobacter sp. ${ }^{6-8} \mathrm{~N}_{2} \mathrm{O}$ also forms as an obligate intermediate product 36 of denitrification under low oxygen conditions through the bacterial reduction of $\mathrm{NO}_{3}{ }^{-}$to nitrogen gas $37\left(\mathrm{~N}_{2}\right){ }^{7-9}$ Furthermore, in oxygen-deficient environments, $\mathrm{NH}_{4}{ }^{+}$can be oxidized to nitrite $\left(\mathrm{NO}_{2}{ }^{-}\right)$and 38 then reduced to nitric oxide (NO), $\mathrm{N}_{2} \mathrm{O}$ and $\mathrm{N}_{2}$ via nitrifier denitrification. ${ }^{10}$

39 Current estimates of the total global flux of $\mathrm{N}_{2} \mathrm{O}$ into the atmosphere as a result of nitrogen (N) 40 cycling are $\sim 18.8 \mathrm{Tg} \mathrm{N} \mathrm{a}^{-1}$, of which $\sim 10.5 \mathrm{Tg} \mathrm{N} \mathrm{a}^{-1}(55 \%)$ originate in natural sources. ${ }^{11}$ The 41 remaining $45 \%$ of emissions are derived from anthropogenic sources $\left(\sim 8.3 \mathrm{Tg} \mathrm{N} \mathrm{a}^{-1}\right)$ as a result of 42 perturbations to the $\mathrm{N}$ cycle. ${ }^{11}$ Agriculture represents the largest anthropogenic source $(5.3-8.0 \mathrm{Tg} \mathrm{N}$ $\left.43 \mathrm{a}^{-1}\right)$ and can be divided into direct emissions from soils $\left(1.8-2.1 \mathrm{Tg} \mathrm{N} \mathrm{a}^{-1}\right)$, animal production $(2.1-$ $\left.442.3 \mathrm{Tg} \mathrm{N} \mathrm{a}^{-1}\right)$ and indirect emissions $\left(1.3-2.6 \mathrm{Tg} \mathrm{N} \mathrm{a}^{-1}\right) \cdot{ }^{11-14}$ Whilst direct soil emissions have been extensively studied, ${ }^{6,15-20}$ indirect emissions arising from atmospheric deposition $(\sim 0.3-0.4 \mathrm{Tg} \mathrm{N} \mathrm{a}$ $\left.{ }^{1}\right)$, human sewage $\left(\sim 0.2-0.3 \mathrm{Tg} \mathrm{N} \mathrm{a}^{-1}\right)$ and $\mathrm{N}$ leaching and runoff $\left(\sim 0.6-1.9 \mathrm{Tg} \mathrm{N} \mathrm{a}^{-1}\right)$ are less well constrained and remain a major source of uncertainty in the global $\mathrm{N}_{2} \mathrm{O}$ budget. ${ }^{21-29}$

48 The Intergovernmental Panel on Climate Change (IPCC) uses emission factors to estimate indirect $49 \mathrm{~N}_{2} \mathrm{O}$ emissions from waterbodies arising from $\mathrm{N}$ leaching and runoff $\left(\mathrm{EF}_{5}\right) .{ }^{13,30}$ These are based either 50 on the fraction $\left(\mathrm{Frac}_{\mathrm{LEACH}}\right)$ of the original total fertilizer $\mathrm{N}$ input into the system that is lost to 51 waterbodies as a result of leaching and runoff from agricultural soils (eq. 1), or simply the ratio of 52 dissolved $\mathrm{N}_{2} \mathrm{O}$ to dissolved inorganic nitrogen (DIN) within the waterbody (eq. 2):

(1) $E F_{5}=\frac{N_{2} O-N}{\left(\text { total } N \text { input } \times \text { Frac } C_{L E A C H}\right)}$

55 (2) $E F_{5}=\frac{\mathrm{N}_{2} \mathrm{O}-\mathrm{N}}{\mathrm{NO}_{3}-\mathrm{N}}$

56 The IPCC divides $\mathrm{EF}_{5}$ into three components based on the site of $\mathrm{N}_{2} \mathrm{O}$ production in either 57 groundwater $\left(\mathrm{EF}_{5 \mathrm{~g}}\right)$, rivers $\left(\mathrm{EF}_{5 \mathrm{r}}\right)$ or estuaries $\left(\mathrm{EF}_{5 \mathrm{e}}\right)$. Since 2006 , each component has been assigned a 58 default value of 0.0025 (i.e. $2.5 \mathrm{~g}$ of $\mathrm{N}_{2} \mathrm{O}-\mathrm{N}$ emitted per $\mathrm{kg}$ of $\mathrm{N}$ in leachate/runoff), thus giving a 59 combined $\mathrm{EF}_{5}$ of $0.0075 .^{30}$ However, these default 'Tier 1 ' emission factors are poorly constrained 60 due to a paucity of studies, highly uncertain water-air gaseous exchange relationships, and large 61 variability in environmental conditions. ${ }^{29}$ Thus, $\mathrm{EF}_{5}$ has a wide range of uncertainty $(0.0005-0.025)$ 62 and has been broadly criticized for either over ${ }^{14,31,32}$ or under ${ }^{9,29}$ estimating actual $\mathrm{N}_{2} \mathrm{O}$ fluxes. 
In order to produce more accurate emission estimates, refined 'Tier 3' $\mathrm{EF}_{5}$ emission factors need to be derived which reflect regional variability in climate, soil type, geology, hydrochemistry, river morphology and land management. ${ }^{14}$, 33 In this research, we investigated the impact of hydrogeological conditions upon riverine $\mathrm{N}_{2} \mathrm{O}$ emissions as a way of generating improved 'regionalscale' $\mathrm{EF}_{5 \mathrm{r}}$ estimates. Focusing on three UK river catchments with contrasting bedrock (chalk, limestone, sandstone, mudstone, volcanic) and superficial (glacial till, glacial sands/gravels, absent) geologies, we explored whether hydrogeological conditions (high/low permeability, confined/unconfined groundwater) exerted a sufficiently robust control over $\mathrm{EF}_{5 \mathrm{r}}$ that it could be used as a proxy for upscaling $\mathrm{N}_{2} \mathrm{O}$ emission estimates that are required for producing national greenhouse gas inventories. We hypothesized such an association could arise due to hydrogeological conditions controlling the infiltration and upwelling of water and dissolved $\mathrm{N}$ fertilizers in catchments, which in turn impacts upon the formation and movement of dissolved $\mathrm{N}_{2} \mathrm{O}$ gas. It is envisaged the outcomes of this research will provide useful evidence for updating indirect $\mathrm{N}_{2} \mathrm{O}$ emission factors used in future IPCC assessment reports.

\section{Materials and Methods}

\subsection{Study Locations}

The three river catchments (Avon, Eden and Wensum) and sampling locations investigated in this study were selected to align with the counterpart UK government-funded Demonstration Test Catchments (DTC) program which is evaluating the extent to which on-farm mitigation measures can cost-effectively reduce the impact of agricultural pollution on river ecology. ${ }^{34}$

\subsubsection{River Wensum}

The River Wensum, Norfolk, is a $78 \mathrm{~km}$ length groundwater-dominated lowland (source $=75 \mathrm{~m}$ above sea level (a.s.1.)) calcareous river that drains an area of $660 \mathrm{~km}^{2}$ and has a mean annual discharge of $4.1 \mathrm{~m}^{3} \mathrm{~s}^{-1}$ near its outlet ${ }^{35}$ (Figure 1; hydrological summaries provided in Figure $\mathrm{S} 1$ and Table S1). The catchment is underlain by Cretaceous White Chalk bedrock which is unconfined in the upper catchment and along sections of the river valley where the baseflow index (BFI) is $\sim 0.7-0.9$. Over much of the rest of the catchment, the Chalk is confined by superficial deposits of MidPleistocene diamicton glacial tills principally comprising chalky, flint-rich boulder clays of the Sheringham Cliffs $(0.2-0.5 \mathrm{~m}$ depth) and Lowestoft $(0.2-20 \mathrm{~m}$ depth) Formations. These are interspersed with layers of glaciofluvial and glaciolacustrine sands and gravels where the BFI is $\sim 0.5-$ 0.7 . Within the river valley, Holocene-age alluvium and river terrace deposits are present. ${ }^{36}$ Surface 
97 grassland and $4 \%$ urban. The mean annual temperature is $10.1{ }^{\circ} \mathrm{C}$ and the mean annual rainfall total is $98 \quad 674 \mathrm{~mm}(1981-2010){ }^{37}$

\subsubsection{River Eden}

The River Eden, Cumbria, is a $145 \mathrm{~km}$ length surface runoff-dominated upland (source $=675 \mathrm{~m}$ a.s.l.) river draining $2288 \mathrm{~km}^{2}$ with a mean annual discharge of $53.4 \mathrm{~m}^{3} \mathrm{~s}^{-1}$ near its outlet. ${ }^{35}$ The catchment bedrock comprises a mixture of Permo-Triassic sandstone, lower Palaeozoic igneous formations (Borrowdale Volcanics) and steeply dipping fractured Carboniferous limestone interbedded with sandstone and mudstone units (Figure 1). Quaternary glacial till confines the majority of the bedrock, varying in thickness from $0-30 \mathrm{~m}$ across the catchment, whilst alluvium is present in the river valley. The BFI in these confined areas is $0.3-0.5$. Soils are mainly sandy clay loam and clay loam; locally deep and well-drained in the headwaters, seasonally wet in the central elevations, moving through to slowly permeable and seasonally waterlogged in lower parts of the catchment. Livestock farming (sheep and dairy) dominates land use, with approximately 50\% of land under improved pasture, 20\% rough grazing, $16 \%$ arable and $8 \%$ mixed woodland. The mean annual temperature is $9.4^{\circ} \mathrm{C}$ and the mean annual precipitation total is $1197 \mathrm{~mm}(1981-2010){ }^{37}$

\subsubsection{River Avon}

The River Avon, Hampshire, is a $96 \mathrm{~km}$ length groundwater-dominated, lowland (source $=120 \mathrm{~m}$ a.s.1.) river draining $1717 \mathrm{~km}^{2}$ with a mean annual discharge of $20.3 \mathrm{~m}^{3} \mathrm{~s}^{-1}$ near its outlet. ${ }^{35}$ Approximately $85 \%$ of the main river flow is supplied by the underlying Cretaceous White Chalk and Upper Greensand bedrock aquifers $(B F I=0.75-0.95)$. The catchment also contains extensive expanses of low permeability Jurassic Kimmeridge Clay mudstone $(\mathrm{BFI}=0.2-0.5)$. The Chalk and mudstone are largely unconfined across the catchment, but are locally covered by pockets of Quaternary alluvium, head and river terrace deposits. Free-draining, shallow, lime-rich soils overlay the Chalk across much of the catchment, alongside smaller areas of low permeability base-rich clay loam. The catchment has a mixed farming system, with $48 \%$ of land under arable cultivation and $32 \%$ in grassland for lowland grazing and intensive dairy production. The mean annual temperature is $10.1^{\circ} \mathrm{C}$ and the mean annual rainfall total is $857 \mathrm{~mm}(1981-2010) .{ }^{37}$

\subsection{Sample Collection}

For the River Wensum, samples were collected from 20 sites across the catchment at approximately monthly intervals between February 2011 and May 2013, such that 26 samples were collected from each site and 520 samples were collected in total (Table 1). Of the 20 sites, 16 were tributary streams $<10$ m width, of which 12 were from sites where the Chalk is confined by glacial deposits $(n=312)$ and four sites where the Chalk is largely unconfined $(n=104)$. A further four sites were located on the main channel of the River Wensum ( $>10 \mathrm{~m}$ width) and drained an upstream area encompassing both 
131 confined and unconfined Chalk; these samples are henceforth referred to as 'semi-confined' Chalk ( $n$ $132=104)$. The higher sampling resolution for the River Wensum enabled temporal variability in $\mathrm{N}_{2} \mathrm{O}$ 133 dynamics to be assessed for this catchment.

134 For the River Avon, samples were collected from six headwater tributaries on four separate occasions 135 (February, June and October 2012, March 2013). 2-3 replicates were collected from each tributary on 136 each sampling occasion, giving 56 samples in total. Of these, 29 samples came from sites on 137 unconfined Chalk and 27 were on unconfined mudstone.

138 For the River Eden, samples were collected from nine headwater tributaries on four occasions (March, 139 June and October 2012, March 2013). 2-3 replicates were collected from each tributary on each 140 sampling occasion, giving 75 samples in total. Of these, 21 samples were from sites on limestone, 27 141 on sandstone and 27 on volcanics, all confined by glacial deposits.

142 Water samples for dissolved $\mathrm{N}_{2} \mathrm{O}$ analysis were collected in $20 \mathrm{~mL}$ glass syringes that were flushed 143 three times with river water and any trapped air expelled before the final sample was taken. Samples 144 were returned to cold storage $\left(4^{\circ} \mathrm{C}\right)$ within $3 \mathrm{~h}$ and analyzed for $\mathrm{N}_{2} \mathrm{O}$ within $72 \mathrm{~h}$ of collection. Water 145 samples for $\mathrm{NO}_{3}{ }^{-}, \mathrm{NO}_{2}{ }^{-}, \mathrm{NH}_{4}{ }^{+}$and dissolved organic carbon (DOC) analysis were grab sampled in $1 \mathrm{~L}$ 146 polypropylene bottles and also analyzed within $72 \mathrm{~h}$ of collection after filtering. For 240 of the River 147 Wensum grab samples collected between May 2012 and May 2013, an aliquot was filtered through a $1480.22 \mu \mathrm{m}$ cellulose acetate filter and frozen at $-20^{\circ} \mathrm{C}$ in preparation for nitrogen and oxygen stable 149 isotope analysis. River water temperatures were measured in-situ with a handheld alcohol 150 thermometer.

\section{$151 \quad 2.3$ Sample Analysis}

152 Dissolved $\mathrm{N}_{2} \mathrm{O}$ concentrations were determined by purge-and-trap gas chromatography with an 153 electron capture detector (Shimadzu GC-ECD) which had a measurement accuracy within $\pm 3 \%$ and a 154 detection limit of $0.0008 \mu \mathrm{g} \mathrm{N} \mathrm{L}{ }^{-1}$. Dissolved $\mathrm{NO}_{3}^{-}$concentrations were determined by ion 155 chromatography (Dionex ICS-2000) with a precision of $\pm 0.2 \mathrm{mg} \mathrm{N} \mathrm{L}^{-1}$, whilst dissolved $\mathrm{NO}_{2}^{-}$and $156 \mathrm{NH}_{4}{ }^{+}$were determined by a continuous flow analyzer (Skalar SAN++) with precisions of \pm 1.5 and 5 $157 \mu \mathrm{g} \mathrm{L}^{-1}$, respectively. DOC was determined by a Shimadzu TOC/TN analyzer with a precision of \pm 0.5 $158 \mathrm{mg} \mathrm{L}^{-1}$. Samples for isotopic analysis were prepared using the denitrifier method and analyzed on a 159 GEO 20:20 GC-IRMS with a TG II prep system with a precision of $\pm 0.4 \%$ for $\delta^{15} \mathrm{~N}_{\mathrm{NO} 3}$ and $\pm 0.6 \%$ for $160 \quad \delta^{18} \mathrm{O}_{\mathrm{NO} 3}($ Table S2).

\subsection{Fluxes and Emission Factors}


$162 \mathrm{~N}_{2} \mathrm{O}$ emission factors for each river water sample were calculated by the mass ratio approach (eq. 2)

163 derived from the measured concentrations of $\mathrm{N}_{2} \mathrm{O}\left(\mathrm{mg} \mathrm{N} \mathrm{L}^{-1}\right)$ and $\mathrm{NO}_{3}{ }^{-}\left(\mathrm{mg} \mathrm{N} \mathrm{L}^{-1}\right)$. Fluxes of $\mathrm{N}_{2} \mathrm{O}$

164 from the river to the atmosphere where calculated using the water-air gas exchange eq. $3:^{38}$

165

166

167

168

169

170

171

172

173

174

175

176

177

178

179

180

181

182

183

184

185

186

187

188

189

190

191

192

193

194

(3) $F=k C_{w}-\frac{C_{a}}{k^{\prime} h}$

where $F$ is the flux of $\mathrm{N}_{2} \mathrm{O}\left(\mathrm{mol} \mathrm{cm} \mathrm{cm}^{-2} \mathrm{~h}^{-1}\right.$, subsequently converted into $\mathrm{kg} \mathrm{N} \mathrm{ha}{ }^{-1} \mathrm{a}^{-1} ; k$ is the gas transfer velocity of $\mathrm{N}_{2} \mathrm{O}$ across the water-air interface $\left(\mathrm{cm} \mathrm{h}^{-1}\right) ; C_{w}$ is the concentration of $\mathrm{N}_{2} \mathrm{O}$ in river water $(\mathrm{mol} \mathrm{cm}) ; C_{a}$ is the concentration of $\mathrm{N}_{2} \mathrm{O}$ in the atmosphere $\left.(\mathrm{mol} \mathrm{cm})^{-3}\right)$; and $k_{h}{ }_{h}$ is the dimensionless Henry's law constant for $\mathrm{N}_{2} \mathrm{O}$. Estimation of the gas transfer velocity represents a major source of uncertainty in water-atmosphere gas flux calculations and currently no definitive method exists to define $k$ values. ${ }^{39,40}$ The use of benthic turbulence models which incorporate aspects of stream velocity, stream depth, bed roughness and bed slope, likely produce more accurate gas exchange rates for small-to-medium sized rivers such as those studied here. ${ }^{41}$ However, with only three of our 35 study sites being gauged (Figure 1), a lack of velocity and depth data meant we instead adopted a wind-based turbulence model where $k$ was calculated as eq. $4:^{42}$

(4) $k=1.91 e^{0.35 U}\left(\frac{S c}{600}\right)^{-0.5}$

where $U$ is the wind speed $\left(\mathrm{m} \mathrm{s}^{-1}\right)$ and $S c$ is the Schmidt number for $\mathrm{N}_{2} \mathrm{O}$ in freshwater adjusted for temperature. ${ }^{43}$ Although likely less accurate than a benthic turbulence model, the approach adopted is consistent across all sites and it yields mean $k$ values of 4.0, 4.5 and 4.6 for the Avon, Eden and Wensum catchments, respectively, which are within the range of 3-7 previously recommended. ${ }^{42}$ Mean wind speed data (15-min resolution) for the time of sample collection were obtained from local weather stations within each catchment.

The $\mathrm{N}_{2} \mathrm{O}$ saturation level (\%) was calculated as eq. $5:^{.28}$

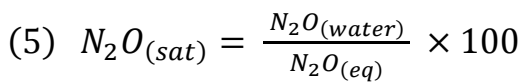

where $\mathrm{N}_{2} \mathrm{O}_{\text {(water) }}$ is the measured $\mathrm{N}_{2} \mathrm{O}$ concentration in river water and $\mathrm{N}_{2} \mathrm{O}_{(\mathrm{eq})}$ is the concentration when water is in equilibrium with the atmosphere. ${ }^{44}$

\section{Results and Discussion}

\subsection{Spatial variability}

In $99.9 \%$ of river water samples, $\mathrm{N}_{2} \mathrm{O}$ saturation levels exceeded the atmospheric equilibrium implying almost all sites were acting as a net source of $\mathrm{N}_{2} \mathrm{O}$ to the atmosphere. Saturation levels ranged from $90-1305 \%($ median $=283 \%)$ for the River Wensum, $116-455 \%($ median $=158 \%)$ for the River Eden and 136-17070\% (median $=1178 \%$ ) for the River Avon. Whilst the Wensum and Eden 
195 values are comparable with other studies, saturation levels in the River Avon are towards the upper 196 end of the range previously reported. ${ }^{14,26,45,46}$

197 Unconfined Chalk regions of the rivers Avon $\left(16.83 \mu \mathrm{g} \mathrm{L}^{-1}\right)$ and Wensum $\left(2.53 \mu \mathrm{g} \mathrm{L}^{-1}\right)$ had the 198 highest median $\mathrm{N}_{2} \mathrm{O}$ concentrations, contributing to a median concentration for all unconfined Chalk 199 sites of $3.03 \mu \mathrm{g} \mathrm{N} \mathrm{L}^{-1}$ (Table 1; Figure 2). Comparatively high median $\mathrm{NO}_{3}{ }^{-}$concentrations were also 200 observed for the unconfined Chalk of the Avon (7.01 mg N L${ }^{-1}$ ) and Wensum $\left(9.21 \mathrm{mg} \mathrm{N} \mathrm{L}^{-1}\right)$, and 201 together these unconfined Chalk regions yielded the highest median $\mathrm{EF}_{5 \mathrm{r}}(0.00036)$ and $\mathrm{N}_{2} \mathrm{O}$ flux $202\left(10.8 \mathrm{~kg} \mathrm{~N} \mathrm{ha}^{-1} \mathrm{a}^{-1}\right)$. These indirect fluxes are towards the upper end of the range previously reported 203 for rivers draining arable and grassland sites in Europe.$^{47}$ However, despite unconfined Chalk regions 204 having the highest $\mathrm{EF}_{5 \mathrm{r}}$ of the different hydrogeological types, the overall median $\mathrm{EF}_{5 \mathrm{r}}$ was 7 times 205 lower than the IPCC default value of 0.0025. Only unconfined Chalk regions of the River Avon had a 206 median $\mathrm{EF}_{5 \mathrm{r}}$ value (0.00235) comparable to the IPCC default.

207 Regions with confined hydrogeological conditions under glacial deposits yielded the lowest riverine $208 \mathrm{~N}_{2} \mathrm{O}$ concentrations, regardless of bedrock type or geographical location. Median $\mathrm{N}_{2} \mathrm{O}$ concentrations 209 in river water samples from confined limestone $\left(0.52 \mu \mathrm{g} \mathrm{N} \mathrm{L}^{-1}\right)$, volcanic $\left(0.57 \mu \mathrm{g} \mathrm{N} \mathrm{L}^{-1}\right)$, sandstone $210\left(0.61 \mu \mathrm{g} \mathrm{N} \mathrm{L}^{-1}\right)$ and Chalk $\left(0.79 \mu \mathrm{g} \mathrm{N} \mathrm{L}^{-1}\right)$ bedrock areas were $\sim 4$ times lower $(t$-test $p<0.05)$ than 211 recorded in rivers draining areas of unconfined Chalk. The confined Wensum Chalk $\left(5.20 \mathrm{mg} \mathrm{N} \mathrm{L}^{-1}\right)$ 212 and confined Eden sandstone (4.52 $\mathrm{mg} \mathrm{N} \mathrm{L}^{-1}$ ) also had lower $\mathrm{NO}_{3}{ }^{-}$concentrations than the unconfined 213 Wensum Chalk sites, although higher riverine $\mathrm{NO}_{3}{ }^{-}$concentrations were recorded on confined 214 limestone (8.61 $\left.\mathrm{mg} \mathrm{N} \mathrm{L}^{-1}\right)$ in the River Eden. Together, the median $\mathrm{EF}_{5 \mathrm{r}}(0.00016)$ and $\mathrm{N}_{2} \mathrm{O}$ flux (2.6 $215 \mathrm{~kg} \mathrm{ha}^{-1} \mathrm{a}^{-1}$ ) for all sites confined by glacial deposits were the lowest and second lowest recorded, 216 respectively, with an emission factor 16 times lower than the IPCC default.

217 The semi-confined Chalk hydrogeological grouping, composed of main River Wensum sites which 218 receive a mix of $\mathrm{N}_{2} \mathrm{O}$ and $\mathrm{NO}_{3}{ }^{-}$enriched water from unconfined Chalk tributaries and $\mathrm{N}_{2} \mathrm{O}$ and $\mathrm{NO}_{3}{ }^{-}$ 219 depleted water from confined Chalk tributaries, had median $\mathrm{N}_{2} \mathrm{O}\left(1.31 \mu \mathrm{g} \mathrm{N} \mathrm{L}^{-1}\right)$ and $\mathrm{NO}_{3}^{-}(5.99 \mathrm{mg} \mathrm{N}$ $\left.220 \mathrm{~L}^{-1}\right)$ concentrations, $\mathrm{EF}_{5 \mathrm{r}}(0.00022)$ and flux rate $\left(5.1 \mathrm{~kg} \mathrm{~N} \mathrm{ha}^{-1} \mathrm{a}^{-1}\right)$ between that of the confined and 221 unconfined sites. However, in pronounced contrast to the unconfined Chalk sites, streams on 222 unconfined mudstone in the River Avon yielded low median $\mathrm{N}_{2} \mathrm{O}\left(0.69 \mu \mathrm{g} \mathrm{N} \mathrm{L}^{-1}\right)$ and $\mathrm{NO}_{3}{ }^{-}(4.46 \mathrm{mg}$ $223 \mathrm{~N} \mathrm{~L}^{-1}$ ) concentrations. This indicates that bedrock permeability may exert an important control on $224 \mathrm{~N}_{2} \mathrm{O}$ production where it is unconfined, with mudstone permeability being substantially lower than 225 that of Chalk. Emission factors for the unconfined mudstone were highly variable, but median values 226 were $\sim 12$ times lower than unconfined Chalk in the same catchment (0.00020), with an emission rate 227 of $2.0 \mathrm{~kg} \mathrm{ha}^{-1} \mathrm{a}^{-1}$.

228 Importantly, despite river discharge varying substantially between sampling locations (Figure S1) 229 there is no evidence of a dilution effect in $\mathrm{N}_{2} \mathrm{O}$ concentrations at the larger main river sites, nor is 
230 there evidence of a strong $\mathrm{N}_{2} \mathrm{O}$ degassing signal as water moves further down the catchment. The 231 hydrogeological conditions at the sampling sites remain the dominant classifier of $\mathrm{N}_{2} \mathrm{O}$ concentration 232 and $\mathrm{EF}_{5 \mathrm{r}}$ regardless of discharge or stream order. Evidence for this can be seen in Table 1, where the 233 semi-confined Chalk grouping of the River Wensum is composed solely of the four main river sample 234 locations which have the greatest discharges and highest stream orders. If downstream degassing and 235 dilution were major controls on $\mathrm{N}_{2} \mathrm{O}$, we would expect these semi-confined sites to have lower $\mathrm{N}_{2} \mathrm{O}$ 236 concentrations than the other 16 Wensum tributary locations, but this is not the case. Instead, median $237 \mathrm{~N}_{2} \mathrm{O}$ concentrations and $\mathrm{EF}_{5 \mathrm{r}}$ values were significantly $(p<0.05)$ higher at the semi-confined main 238 river sites $\left(\mathrm{N}_{2} \mathrm{O}=1.31 \mu \mathrm{g} \mathrm{N} \mathrm{L}^{-1} ; \mathrm{EF}_{5 \mathrm{r}}=0.00022\right)$ than recorded in the confined upstream tributary 239 locations $\left(\mathrm{N}_{2} \mathrm{O}=0.79 \mu \mathrm{g} \mathrm{N} \mathrm{L}{ }^{-1} ; \mathrm{EF}_{5 \mathrm{r}}=0.00016\right)$. Similarly, we also observe that despite having 240 substantially higher discharge (Figure S1), confined tributary sites in the River Eden yield comparable 241 median $\mathrm{N}_{2} \mathrm{O}$ concentrations $\left(0.52-0.61 \mu \mathrm{g} \mathrm{N} \mathrm{L}^{-1}\right)$ and $\mathrm{EF}_{5 \mathrm{r}}$ values $(0.00007-0.00019)$ to the confined 242 tributary locations in the River Wensum.

\section{$243 \quad 3.2$ Temporal variability}

244 Seasonally, riverine $\mathrm{N}_{2} \mathrm{O}$ and $\mathrm{NO}_{3}{ }^{-}$concentrations were lowest during spring (MAM) and summer 245 (JJA), respectively, regardless of hydrogeological conditions (Table 2). Likewise, the highest $\mathrm{NO}_{3}{ }^{-}$ 246 concentrations typically occurred across all locations during the winter (DJF), consistent with higher $247 \mathrm{~N}$ leaching rates under wetter antecedent conditions. Highest $\mathrm{N}_{2} \mathrm{O}$ concentrations did, however, differ 248 by hydrogeological type, being greatest during summer and autumn (SON) in unconfined and semi249 confined regions, and during winter in areas of confined Chalk. Emission factors were highest during 250 summer/autumn and lowest during spring, irrespective of hydrogeological type, with these seasonal 251 contrasts being statistically significant ( $t$-test $p<0.05$ ). Such patterns are broadly consistent with the 252 temporal variability in $\mathrm{N}_{2} \mathrm{O}$ concentrations reported previously, ${ }^{26,48}, 49$ and demonstrate that 253 application of a single default $\mathrm{EF}_{5 \mathrm{r}}$ value fails to capture the significant temporal variability in $\mathrm{N}_{2} \mathrm{O}$ 254 dynamics and could lead to a misrepresentation of the true $\mathrm{N}_{2} \mathrm{O}$ flux. Here, median $\mathrm{N}_{2} \mathrm{O}$ flux rates 255 were greatest during winter irrespective of hydrogeological conditions due to significantly higher 256 wind speeds at this time of year yielding a higher gas transfer velocity for the wind disturbance-based 257 Equation 4.

258 Unconfined Chalk sites consistently had the highest dissolved $\mathrm{N}_{2} \mathrm{O}$ concentrations throughout the 28259 month period, with concentrations ranging from 0.81-4.70 $\mathrm{g} \mathrm{L}^{-1}$ (Figure 3). Conversely, at Chalk 260 sites confined by glacial deposits $\mathrm{N}_{2} \mathrm{O}$ concentrations were consistently the lowest and least variable, 261 ranging from $0.32-2.35 \mu \mathrm{g} \mathrm{L}^{-1}$. The semi-confined Chalk sites were intermediate to the confined and 262 unconfined locations. Peaks in $\mathrm{N}_{2} \mathrm{O}$ concentration (e.g. December 2011, June 2012) were associated 263 with rainfall events $<24 \mathrm{~h}$ before sample collection, which also yielded peaks in the concentration of $264 \mathrm{NO}_{3}{ }^{-}$(Figure S2), $\mathrm{NH}_{4}$ (Figure S3), $\mathrm{NO}_{2}{ }^{-}$(Figure S4) and in $\mathrm{EF}_{5 \mathrm{r}}$ values (Figure S6). Note that the 
265 IPCC typically derives $\mathrm{EF}_{5 \mathrm{r}}$ values based on annual $\mathrm{N}$ loads and annual $\mathrm{N}_{2} \mathrm{O}$ emissions and thus the 266 instantaneous $\mathrm{EF}_{5 \mathrm{r}}$ values presented in Figure $\mathrm{S} 6$ will inherently exhibit greater temporal variability.

\section{$267 \quad 3.3$ Controls on $\mathbf{N}_{2} \mathbf{O}$ dynamics}

268 It is clear from these data that $\mathrm{N}_{2} \mathrm{O}$ concentrations, fluxes and emission factors vary between regions 269 of contrasting hydrogeological conditions and it is important to understand why this differentiation 270 occurs in order to confidently upscale $\mathrm{EF}_{5 \mathrm{r}}$ estimates nationally based on this characteristic. We 271 hypothesize that in all three catchments, fertilizer inputs are hydrolyzed to $\mathrm{NH}_{4}{ }^{+}$and readily nitrified 272 to $\mathrm{NO}_{3}{ }^{-}$in the soil with further nitrification occurring in stream. In unconfined Chalk regions, $\mathrm{NO}_{3}{ }^{-}$ 273 and $\mathrm{N}_{2} \mathrm{O}$ from the soil are rapidly transported in infiltrating water down to the well-mixed 274 groundwater zone in the high permeability Chalk. As $\mathrm{N}_{2} \mathrm{O}$ and $\mathrm{NO}_{3}{ }^{-}$enriched groundwater comprises 275 the major proportion of river flow in these regions $(\mathrm{BFI}=0.70-0.95)$, high $\mathrm{N}_{2} \mathrm{O}$ and $\mathrm{NO}_{3}{ }^{-}$ 276 concentrations are subsequently observed instream, alongside elevated $\mathrm{EF}_{5 \mathrm{r}}$ values. Conversely, in 277 regions of confined groundwater and smaller BFI (0.40-0.70), lower permeability glacial deposits 278 reduce infiltration rates and allow low oxygen conditions to develop where denitrification and/or 279 nitrifer denitrification can occur before the infiltrating water recharges groundwater. This process 280 partially protects groundwater from $\mathrm{NO}_{3}{ }^{-}$leaching and results in lower $\mathrm{NO}_{3}{ }^{-}$and $\mathrm{N}_{2} \mathrm{O}$ concentrations 281 at these sites. ${ }^{50}$ Although regions of unconfined mudstone are not protected by overlying glacial 282 deposits, the lower permeability of the mudstone relative to the Chalk results in similar opportunities 283 for denitrification and/or nitrifier denitrification, thus resulting in lower $\mathrm{NO}_{3}{ }^{-}$concentrations, reduced 284 rates of soil-to-river $\mathrm{N}_{2} \mathrm{O}$ transfer and lower $\mathrm{EF}_{5 \mathrm{r}}$ values. This hypothesis is supported by the stable 285 isotope data (Figure 4b).

286 The nitrogen $\left(\delta^{15} \mathrm{~N}\right)$ and oxygen $\left(\delta^{18} \mathrm{O}\right)$ isotopic composition of $\mathrm{NO}_{3}{ }^{-}$can be used to infer mixing of 287 sources of $\mathrm{NO}_{3}{ }^{-}$with differing isotopic composition and to indicate the dominance of nitrification and 288 denitrification (see Supporting Information). The fractionation ratio of $\delta^{15} \mathrm{~N}_{\mathrm{NO} 3}$ to $\delta^{18} \mathrm{O}_{\mathrm{NO} 3}$ for the 289 Wensum samples is 0.41 (Figure 4b), providing some evidence of denitrification across the catchment 290 drainage network. Mixing of atmospheric and fertilizer direct $\mathrm{NO}_{3}{ }^{-}$sources with partially denitrified $291 \mathrm{NO}_{3}{ }^{-}$raises the bulk $\delta^{18} \mathrm{O}_{\mathrm{NO} 3}$ and produces scatter above the denitrification slope (Figure $4 \mathrm{~b}$ ). 292 Variation in pre-nitrification $\delta^{15} \mathrm{~N}_{\mathrm{NH} 4}$ is reflected in post-nitrification $\delta^{15} \mathrm{~N}_{\mathrm{NO} 3}$, producing scatter on the $293 \delta^{15} \mathrm{~N}_{\mathrm{NO} 3}$ axis. Together these mixing effects result in a weak relationship between $\delta^{18} \mathrm{O}_{\mathrm{NO} 3}$ and $\delta^{15} \mathrm{~N}_{\mathrm{NO} 3}$ $294 \quad\left(\mathrm{R}^{2}=0.375\right)$, reflecting the combined effects of mixing and denitrification.

295 The heaviest expected $\delta^{18} \mathrm{O}_{\mathrm{NO} 3}$ produced from nitrification of $\mathrm{NH}_{4}{ }^{+}$in the Wensum catchment is $2963.8 \%{ }^{51}$ This value is derived from the incorporation of oxygen from ambient water and air during 297 nitrification at an initial ratio of $2: 1,{ }^{52,53}$ as well as from measurements of $\delta^{18} \mathrm{O}_{\mathrm{H} 2 \mathrm{O}}$ in rivers, 298 tributaries, field drains, streambed piezometers and boreholes in the Wensum catchment $\left(\delta^{18} \mathrm{O}_{\mathrm{H} 2 \mathrm{O}}=\right.$ $2996.0 \%$ to $-7.5 \%$ o). ${ }^{50}$ This upper limit would not be affected by any abiotic oxygen exchange between 
$300 \mathrm{NO}_{2}{ }^{-}$and $\mathrm{H}_{2} \mathrm{O},{ }^{54}$ because this would result in isotopically lighter $\delta^{18} \mathrm{O}_{\mathrm{NO} 3}$. Fertilizer and precipitation 301 direct sources of $\mathrm{NO}_{3}{ }^{-}\left(\delta^{18} \mathrm{O}_{\mathrm{NO} 3}>20 \%\right)$ have $\delta^{18} \mathrm{O}_{\mathrm{NO} 3}$ values clearly differentiated from that of $\mathrm{NO}_{3}{ }^{-}$

302 produced from nitrification in the Wensum catchment, thus $\delta^{18} \mathrm{O}_{\mathrm{NO} 3} \leq 3.8 \%$ can be used as an 303 indicator of $\mathrm{NO}_{3}{ }^{-}$from nitrification (Figure $4 \mathrm{~b}$ ).

304 There is a positive relationship between the relative dominance of nitrification $\mathrm{NO}_{3}{ }^{-}$and median $\mathrm{N}_{2} \mathrm{O}$ 305 concentrations with hydrogeological setting. The highest proportion of samples containing 306 nitrification $\mathrm{NO}_{3}{ }^{-}\left(\delta^{18} \mathrm{O}_{\mathrm{NO} 3} \leq 3.8 \%\right.$ ) were from unconfined Chalk sites (42\% of 48 samples). These 307 sites also produced the highest median $\mathrm{N}_{2} \mathrm{O}$ concentrations $\left(2.53 \mu \mathrm{g} \mathrm{N} \mathrm{N}_{2} \mathrm{O} \mathrm{L}^{-1}\right)$. In comparison, the 308 confined Chalk produced the lowest proportion of samples containing nitrification $\mathrm{NO}_{3}{ }^{-}(7 \%$ of 132 309 samples), with the lowest median $\mathrm{N}_{2} \mathrm{O}$ concentrations $\left(0.79 \mu \mathrm{g} \mathrm{N}_{2} \mathrm{O} \mathrm{L}^{-1}\right)$. The proportion of 310 nitrification $\mathrm{NO}_{3}{ }^{-}$from semi-confined sites was between that of unconfined and confined Chalk sites 311 (22\% of 60 samples) with a median $\mathrm{N}_{2} \mathrm{O}$ concentration of $1.31 \mu \mathrm{g} \mathrm{N} \mathrm{N}_{2} \mathrm{~L}^{-1}$. This relationship indicates 312 that nitrification, rather than denitrification, is the dominant $\mathrm{N}_{2} \mathrm{O}$ production process in the Wensum 313 catchment. We suggest that in unconfined Chalk sites, infiltration of recharge water occurs rapidly to 314 well-mixed shallow groundwater. Baseflow transports dissolved nitrification $\mathrm{NO}_{3}{ }^{-}$, by-product $\mathrm{N}_{2} \mathrm{O}$ 315 and denitrification-inhibiting dissolved oxygen (DO saturation $=89-97 \%{ }^{50}$ ) into the river. 316 Denitrification may also be inhibited in the unconfined sites by a relatively low availability of labile 317 carbon, with a mean DOC: $\mathrm{NO}_{3}{ }^{-}$ratio $<1$ at unconfined Chalk sites and $>1$ at confined sites.

318 Across all hydrogeological types in the Wensum catchment, $\mathrm{N}_{2} \mathrm{O}$ concentrations and saturation levels 319 were only weakly correlated with $\mathrm{pH}\left(R^{2}=<0.08\right)$ and water temperature $\left(R^{2}=<0.07\right)$, indicating 320 these variables were not directly acting as abiotic controls on $\mathrm{N}_{2} \mathrm{O}$ production (Figure S9). Stronger 321 negative correlations were, however, established between $\mathrm{EF}_{5 \mathrm{r}}$ and total $\mathrm{N}\left(R^{2}=0.35-0.59\right)$ providing 322 evidence of decreasing (de)nitrification efficiency with increasing $\mathrm{N}$ inputs due to progressive 323 biological saturation. ${ }^{31}$ Low $\mathrm{NH}_{4}{ }^{+}$concentrations at unconfined Chalk sites indicate nitrification is 324 acting as a sink for $\mathrm{NH}_{4}^{+}$(Figure S9).

\section{$325 \quad 3.4$ Implications and recommendations}

326 The evidence presented here clearly demonstrates that $\mathrm{N}_{2} \mathrm{O}$ emission factors vary significantly 327 between regions of contrasting hydrogeological type. Given the inherent regional nature of 328 hydrogeological variability as determined by the distribution of bedrock and superficial geologies, this 329 robust association with $\mathrm{EF}_{5 \mathrm{r}}$ values indicates that hydrogeological conditions could be used as a 330 defining environmental characteristic for upscaling $\mathrm{N}_{2} \mathrm{O}$ emission estimates. Undoubtedly there is a 331 need to further explore whether this association is maintained across a wider range of hydrogeological 332 settings than those investigated here. Nevertheless, regional variability in hydrogeological conditions 333 could be used to generate improved regional-scale $\mathrm{EF}_{5 \mathrm{r}}$ estimates that are essential for developing 334 more accurate national greenhouse gas inventories. Such an approach would address the pressing need 
to produce more refined $\mathrm{EF}_{5}$ values than the current broad-brush method adopted by the IPCC; a call which has been repeatedly emphasized in numerous studies over the past decade. ${ }^{14,26,32,38}$ The unsuitable nature of the default $\mathrm{IPCC}_{\mathrm{EF}}$ value is again highlighted here with $98 \%$ of samples having an $\mathrm{EF}_{5 \mathrm{r}}$ lower than the default 0.0025 value, this despite the downward revision of $\mathrm{EF}_{5 \mathrm{r}}$ during the 2006 IPCC Fourth Assessment Report. ${ }^{30}$ We therefore encourage researchers to investigate if the association between hydrogeology and $\mathrm{EF}_{5 \mathrm{r}}$ is maintained across contrasting river basins. If it is, it should be possible to calibrate hydrogeological-specific $\mathrm{EF}_{5 \mathrm{r}}$ emission factors which can be overlain onto existing global spatial lithological ${ }^{55,56}$ and hydrological ${ }^{57}$ databases as a means of effectively upscaling indirect $\mathrm{N}_{2} \mathrm{O}$ emissions from rivers draining defined hydrogeological regions.

\section{Supporting Information}

The Supporting Information contains hydrological summaries for the study locations (Figure S1; Table S1); description of the laboratory procedures; water quality time-series for the River Wensum (Figures S2-S7); extended discussion of the stable isotope data (Figure S8; Table S2); and regression plots for nitrogen species (Figure S9). The project data are provided in Excel spreadsheet format.

\section{Author Information}

*Corresponding Author: Richard J. Cooper; Richard.J.Cooper@uea.ac.uk; +44(0)1603592922;

School of Environmental Sciences, University of East Anglia, Norwich Research Park, Norwich NR4 7TJ, UK

\section{Acknowledgements}

This research was funded by Defra under the UK Inventory of Agricultural Greenhouse Gas Emissions Platform (AC0116). We are grateful to the Avon and Eden Demonstration Test Catchments for providing logistical support and to Lee Gumm for assistance with data analysis.

\section{References}

1. Myhre, G.; Shindell, D.; Bréon, F.-M.; Collins, W.; Fuglestvedt, J.; J., H.; Koch, D.; Lamarque, J.-F.; Lee, D.; Mendoza, B.; Nakajima, T.; Robock, A.; Stephens, G.; Takemura, T.; Zhang, H., Anthropogenic and Natural Radiative Forcing. In Climate Change 2013: The Physical Science Basis. Contribution of Working Group I to the Fifth Assessment Report of the Intergovernmental Panel on Climate Change., Stocker, T. F.; Qin, D.; Plattner, G.-K.; Tignor, M.; Allen, S. K.; Boschung, J.; Nauels, A.; Xia, Y.; V., B.; Midgley, P. M., Eds. Cambridge University Press, Cambridge, United Kingdom: 2013.

2. NOAA Earth System Research Laboratory. https://www.esrl.noaa.gov/gmd/dv/data/?parameter name=Nitrous\%2BOxide (03/03/2017), 3. Hartmann, D. L.; Klein Tank, A. M. G.; Rusticucci, M.; Alexander, L. V.; Brönnimann, S.; Charabi, Y.; Dentener, F. J.; Dlugokencky, E. J.; Easterling, D. R.; Kaplan, A.; Soden, B. J.; Thorne, P. W.; Wild, M.; Zhai, P. M., Observations: Atmosphere and Surface. In Climate Change 2013: The Physical Science Basis. Contribution of Working Group I to the Fifth Assessment Report of the Intergovernmental Panel on Climate Change, Stocker, T. F.; Qin, D.; Plattner, G.-K.; Tignor, M.; 
372 Allen, S. K.; Boschung, J.; Nauels, A.; Xia, Y.; Bex, V.; Midgley, P. M., Eds. Cambridge University 373 Press, Cambridge, United Kingdom: 2013.

374 4. Ravishankara, A. R.; Daniel, J. S.; Portmann, R. W., Nitrous oxide $\left(\mathrm{N}_{2} \mathrm{O}\right)$ : the dominant

ozone-depleting substance emitted in the 21 st century. Science 2009, 326, 123-125.

5. Davidson, E. A., The contribution of manure and fertilizer nitrogen to atmospheric nitrous oxide since 1860. Nature Geoscience 2009, 2, (9), 659-662.

6. Bremner, J. M.; Blackmer, A. M., Nitrous oxide: emission from soils during nitrification of fertilizer nitrogen. Science 1978, 199, (4326), 295-296.

7. $\quad$ Strauss, E. A.; Richardson, W. B.; Bartsch, L. A.; Cavanaugh, J. C.; Bruesewitz, D. A.; Imker, H.; Heinz, J. A.; Soballe, D. M., Nitrification in the Upper Mississippi River: patterns, controls, and contribution to the $\mathrm{NO}_{3}$ budget. Journal of the North American Benthological Society 2004, 23, (1), 1-14.

8. $\quad$ Mulholland, P. J.; Helton, A. M.; Poole, G. C.; Hall, R. O.; Hamilton, S. K.; Peterson, B. J.; Tank, J. L.; Ashkenas, L. R.; Cooper, L. W.; Dahm, C. N.; Dodds, W. K.; Findlay, S. E.; Gregory, S. V.; Grimm, N. B.; Johnson, S. L.; McDowell, W. H.; Meyer, J. L.; Valett, H. M.; Webster, J. R.; Arango, C. P.; Beaulieu, J. J.; Bernot, M. J.; Burgin, A. J.; Crenshaw, C. L.; Johnson, L. T.; Niederlehner, B. R.; O'Brien, J. M.; Potter, J. D.; Sheibley, R. W.; Sobota, D. J.; Thomas, S. M., Stream denitrification across biomes and its response to anthropogenic nitrate loading. Nature $\mathbf{2 0 0 8 ,}$ 452, (7184), 202-205.

9. $\quad$ Beaulieu, J. J.; Tank, J. L.; Hamilton, S. K.; Wollheim, W. M.; Hall, R. O.; Mulholland, P. J.; Peterson, B. J.; Ashkenas, L. R.; Cooper, L. W.; Dahm, C. N.; Dodds, W. K.; Grimm, N. B.; Johnson, S. L.; McDowell, W. H.; Poole, G. C.; Maurice Valett, H.; Arango, C. P.; Bernot, M. J.; Burgin, A. J.; Crenshaw, C. L.; Helton, A. M.; Johnson, L. T.; O’Brien, J. M.; Potter, J. D.; Sheibley, R. W.; Sobota, D. J.; Thomas, S. M., Nitrous oxide emission from denitrification in stream and river networks. PNAS 2011, 108, (1), 214-219.

10. Kool, D. M.; Dolfing, J.; Wrage, N.; Van Groenigen, J. W., Nitrifier denitrification as a distinct and significant source of nitrous oxide from soil. Soil Biology and Biochemistry 2011, 43, (1), 174-178.

11. Syakila, A.; Kroeze, C., The global nitrous oxide budget revisited. Greenhouse Gas Measurement and Management 2011, 1, (1), 17-26.

12. Mosier, A.; Kroeze, C.; Nevison, C.; Oenema, O.; Seitzinger, S.; van Cleemput, O., Closing the global N2O budget: nitrous oxide emissions through the agricultural nitrogen cycle. Nutrient Cycling in Agroecosystems 1998, 52, 225-248.

13. Nevison, C., Review of the IPCC methodology for estimating nitrous oxide emissions associated with agricultural leaching and runoff. Chemosphere 2000, 2, 493-500.

14. Clough, T. J.; Buckthought, L. E.; Kelliher, F. M.; Sherlock, R. R., Diurnal fluctuations of dissolved nitrous oxide (N2O) concentrations and estimates of $\mathrm{N} 2 \mathrm{O}$ emissions from a spring-fed river: implications for IPCC methodology. Global Change Biology 2007, 13, (5), 1016-1027.

15. Bouwman, A. F., Direct emission of nitrous oxide from agricultural soils. Nutrient Cycling in Agroecosystems 1996, 46, 53-70.

16. Davidson, E. A.; Kingerlee, W., A global inventory of nitric oxide emissions from soils. Nutrient Cycling in Agroecosystems 1997, 48, 14.

17. Lesschen, J. P.; Velthof, G. L.; de Vries, W.; Kros, J., Differentiation of nitrous oxide emission factors for agricultural soils. Environ Pollut 2011, 159, (11), 3215-22.

18. Smith, K. A.; Dobbie, K. E.; Thorman, R.; Watson, C. J.; Chadwick, D. R.; Yamulki, S.; Ball, B. C., The effect of $\mathrm{N}$ fertilizer forms on nitrous oxide emissions from $\mathrm{UK}$ arable land and grassland. Nutrient Cycling in Agroecosystems 2012, 93, 127-149.

19. Butterbach-Bahl, K.; Baggs, E. M.; Dannenmann, M.; Kiese, R.; Zechmeister-Boltenstern, S., Nitrous oxide emissions from soils: how well do we understand the processes and their controls?

Philos Trans R Soc Lond B Biol Sci 2013, 368, (1621), 20130122.

20. $\quad$ Griffis, T. J.; Lee, X.; Baker, J. M.; Russelle, M. P.; Zhang, X.; Venterea, R.; Millet, D. B., Reconciling the differences between top-down and bottom-up estimates of nitrous oxide emissions for the U.S. Corn Belt. Global Biogeochemical Cycles 2013, 27, (3), 746-754.

21. Reay, D. S.; Davidson, E. A.; Smith, K. A.; Smith, P.; Melillo, J. M.; Dentener, F.; Crutzen, P. J., Global agriculture and nitrous oxide emissions. Nature Climate Change 2012, 2, (6), 410-416. 
427

428

429

430

431

432

433

434

435

436

437

438

439

440

441

442

443

444

445

446

447

448

449

450

451

452

453

454

455

456

457

458

459

460

461

462

463

464

465

466

467

468

469

470

471

472

473

474

475

476

477

478

479

480

22. Reay, D. S.; Smith, K. A.; Edwards, A. C., Nitrous oxide emission from agricultural drainage waters. Global Change Biology 2003, 9, 195-203.

23. Reay, D. S.; Smith, K. A.; Edwards, A. C.; Hiscock, K. M.; Dong, L. F.; Nedwell, D. B., Indirect nitrous oxide emissions: Revised emission factors. Environmental Sciences 2005, 2, (2-3), 153-158.

24. Well, R.; Weymann, D.; Flessa, H., Recent research progress on the significance of aquatic systems for indirect agricultural N2O emissions. Environmental Sciences 2005, 2, (2-3), 143-151.

25. Beaulieu, J. J.; Arango, C. P.; Hamilton, S. K.; Tank, J. L., The production and emission of nitrous oxide from headwater streams in the Midwestern United States. Global Change Biology 2008, $14,(4), 878-894$.

26. Hinshaw, S. E.; Dahlgren, R. A., Dissolved nitrous oxide concentrations and fluxes from the eutrophic San Joaquin River, California. Environ Sci Technol 2013, 47, (3), 1313-1322.

27. Yu, Z.; Deng, H.; Wang, D.; Ye, M.; Tan, Y.; Li, Y.; Chen, Z.; Xu, S., Nitrous oxide emissions in the Shanghai river network: implications for the effects of urban sewage and IPCC methodology. Glob Chang Biol 2013, 19, (10), 2999-3010.

28. Chen, N.; Wu, J.; Zhou, X.; Chen, Z.; Lu, T., Riverine N2O production, emissions and export from a region dominated by agriculture in Southeast Asia (Jiulong River). Agriculture, Ecosystems \& Environment 2015, 208, 37-47.

29. Turner, P. A.; Griffis, T. J.; Lee, X.; Baker, J. M.; Venterea, R. T.; Wood, J. D., Indirect nitrous oxide emissions from streams within the US Corn Belt scale with stream order. Proc Natl Acad Sci U S A 2015, 112, (32), 9839-9843.

30. De Klein, C.; Novoa, R. S. A.; Ogle, S.; Smith, K. A.; Rochette, P.; Wirth, T. C., $\mathrm{N}_{2} \mathrm{O}$ emissions from managed soils, and $\mathrm{CO}_{2}$ emissions from lime and urea application. In 2006 IPCC guidelines for national greenhouse gas inventories, Cambridge University Press, Cambridge, United Kingdom: 2006; p 54.

31. $\mathrm{Hu}, \mathrm{M}$;; Chen, D.; Dahlgren, R. A., Modeling nitrous oxide emission from rivers: a global assessment. Glob Chang Biol 2016, 22, (11), 3566-3582.

32. Hama-Aziz, Z. Q.; Hiscock, K. M.; Cooper, R. J., Indirect Nitrous Oxide Emission Factors for Agricultural Field Drains and Headwater Streams. Environ Sci Technol 2017, 51, (1), 7.

33. Skiba, U.; Jones, S. K.; Dragosits, U.; Drewer, J.; Fowler, D.; Rees, R. M.; Pappa, V. A.; Cardenas, L.; Chadwick, D.; Yamulki, S.; Manning, A. J., UK emissions of the greenhouse gas nitrous oxide. Philos Trans R Soc Lond B Biol Sci 2012, 367, (1593), 1175-1185.

34. McGonigle, D. F.; Burke, S. P.; Collins, A. L.; Gartner, R.; Haft, M. R.; Harris, R. C.; Haygarth, P. M.; Hedges, M. C.; Hiscock, K. M.; Lovett, A. A., Developing Demonstration Test Catchments as a platform for transdisciplinary land management research in England and Wales. Environ Sci Process Impacts 2014, 16, (7), 1618-1628.

35. CEH National River Flow Archive. https://nrfa.ceh.ac.uk/data/search (17/07/2017),

36. Hiscock, K. M.; Dennis, P. F.; Saynor, P. R.; Thomas, M. O., Hydrochemical and stable isotope evidence for the extent and nature of the effective Chalk aquifer of north Norfolk, UK. Journal of Hydrology 1996, 180, 29.

37. Meteorological-Office UK Climate Averages.

http://www.metoffice.gov.uk/public/weather/climate/?tab=climateStations (17/07/2017),

38. Outram, F. N.; Hiscock, K. M., Indirect nitrous oxide emissions from surface water bodies in a lowland arable catchment: a significant contribution to agricultural greenhouse gas budgets?

Environ Sci Technol 2012, 46, (15), 8156-8163.

39. Beaulieu, J. J.; Shuster, W. D.; Rebholz, J. A., Controls on gas transfer velocities in a large river. Journal of Geophysical Research: Biogeosciences 2012, 117, (G2).

40. Raymond, P. A.; Zappa, C. J.; Butman, D.; Bott, T. L.; Potter, J.; Mulholland, P.; Laursen, A. E.; McDowell, W. H.; Newbold, D., Scaling the gas transfer velocity and hydraulic geometry in streams and small rivers. Limnology and Oceanography: Fluids and Environments 2012, 2, (1), 41 53.

41. Baulch, H. M.; Venkiteswaran, J. J.; Dillon, P. J.; Maranger, R., Revisiting the application of open-channel estimates of denitrification. Limnology and Oceanography: Methods 2010, 8, (5), 202215. 
42. Raymond, P. A.; Cole, J., Gas exchange in rivers and estuaries: choosing a gas transfer velocity. Estuaries 2001, 24, (2), 312-317.

43. Wanninkhof, R., Relationship between wind speed and gas exchange over the ocean. Journal of Geophysical Research 1992, 97, (C5), 7373-7382.

44. Weiss, R. F.; Price, B. A., Nitrous oxide solubility in water and seawater. Marine Chemistry 1980, $8,13$.

45. Cole, J.; Caraco, N., Emissions of nitrous oxide $\left(\mathrm{N}_{2} \mathrm{O}\right)$ from a tidal, freshwater river, the Hudson River, New York. Environmental Science \& Technology 2001, 35, (6), 6.

46. Xia, Y.; Li, Y.; Li, X.; Guo, M.; She, D.; Yan, X., Diurnal pattern in nitrous oxide emissions from a sewage-enriched river. Chemosphere 2013, 92, (4), 421-428.

47. Garnier, J.; Billen, G.; Vilain, G.; Martinez, A.; Silvestre, M.; Mounier, E.; Toche, F., Nitrous oxide $\left(\mathrm{N}_{2} \mathrm{O}\right)$ in the Seine river and basin: Observations and budgets. Agriculture, Ecosystems \& Environment 2009, 133, (3-4), 223-233.

48. Wilcock, R. J.; Sorrell, B. K., Emissions of Greenhouse Gases CH4 and N2O from Lowgradient Streams in Agriculturally Developed Catchments. Water, Air, and Soil Pollution 2008, 188, (1-4), 155-170.

49. Hama-Aziz, Z. Q.; Hiscock, K. M.; Cooper, R. J., Dissolved nitrous oxide $\left(\mathrm{N}_{2} \mathrm{O}\right)$ dynamics in agricultural field drains and headwater streams in an intensive arable catchment. Hydrological Processes 2017, 31, (6), 1371-1381.

50. Wexler, S. K. An investigation into the sources, cycling and attenuation of nitrate in an agricultural lowland catchment using stable isotopes of nitrogen and oxygen in nitrate. University of East Anglia, 2011.

51. Wexler, S. K.; Hiscock, K. M.; Dennis, P. F., Catchment-scale quantification of hyporheic denitrification using an isotopic and solute flux approach. Environ Sci Technol 2011, 45, (9), 39673973.

52. Andersson, K. K.; Hooper, A. B., $\mathrm{O}_{2}$ and $\mathrm{H}_{2} \mathrm{O}$ are each the source of one $\mathrm{O}$ in $\mathrm{NO}^{-2}$ produced from $\mathrm{NH}_{3}$ by Nitrosomonas: ${ }^{15} \mathrm{~N}-\mathrm{NMR}$ evidence. FEBS Letters 1983, 164, (2), 236-240.

53. Kumar, S.; Nicholas, D. J. D.; Williams, E. H., Definitive ${ }^{15} \mathrm{~N}$ NMR evidence that water serves as a source of 'O' during nitrite oxidation by Nitrobacter agilis. FEBS Letters 1983, 152, (1), $71-74$.

54. Snider, D. M.; Spoelstra, J.; Schiff, S. L.; Venkiteswaran, J. J., Stable oxygen isotope ratios of nitrate produced from nitrification: ${ }^{18} \mathrm{O}$-labeled water incubations of agricultural and temperate forest soils. Environmental Science \& Technology 2010, 44, 5358-5364.

55. Gleeson, T.; Smith, L.; Moosdorf, N.; Hartmann, J.; Dürr, H. H.; Manning, A. H.; van Beek, L. P. H.; Jellinek, A. M., Mapping permeability over the surface of the Earth. Geophysical Research Letters 2011, 38, (2), L02401.

56. Dürr, H. H.; Meybeck, M.; Dürr, S. H., Lithologic composition of the Earth's continental surfaces derived from a new digital map emphasizing riverine material transfer. Global Biogeochemical Cycles 2005, 19, (4), GB4S10.

57. Doll, P.; Fiedler, K., Global-scale modeling of groundwater recharge. Hydrology and Earth System Sciences 2008, 12, 863-885. 


\section{$530 \quad$ Figure Captions}

531 Figure 1: Location of the three UK study catchments with associated bedrock and superficial 532 geologies. Based upon DiGMapGB-625, with the permission of the British Geological Survey.

533 Figure 2: Violin plot summaries of (a) dissolved nitrous oxide concentration, (b) nitrate 534 concentration, (c) $\mathrm{EF}_{5 \mathrm{r}}$ emission factor and (d) nitrous oxide flux for all river water samples by 535 hydrogeological type. Various includes limestone, chalk, sandstone and volcanic bedrock.

536 Figure 3: Time-series of dissolved nitrous oxide concentrations in the River Wensum catchment between February 2011 and May 2013.

Figure 4: (a) Dissolved nitrous oxide and nitrate concentrations for all catchments grouped by hydrogeological type. Various includes limestone, chalk, sandstone and volcanic bedrock. Lines are linear regressions; (b) Stable isotope composition of nitrogen and oxygen in nitrate for River Wensum samples collected between May 2012 and May 2013. Diagonal line represents the denitrification isotope effect (regression line for all data; $\mathrm{R}^{2}=0.375$ ). Dark grey area delineates expected range of isotopic composition from 'nitrification' nitrate in the Wensum catchment. Vertical and horizontal 


\section{Tables}

565

566 Table 1: Summary river water data for different catchments and contrasting hydrogeological types. Values 567 presented as medians with one standard deviation in parentheses. Different superscript letters denote significant 568 differences $(t$-test $p<0.05)$ between hydrogeological types within each catchment.

\begin{tabular}{|c|c|c|c|c|c|c|c|}
\hline Catchment & Bedrock & Hydrogeological type & $\begin{array}{r}N \\
\text { samples }\end{array}$ & $\begin{array}{r}N_{2} \mathbf{O} \\
\left(\mu g \mathrm{~N} \mathrm{~L}^{-1}\right)\end{array}$ & $\begin{array}{r}\mathrm{NO}_{3}^{-} \\
\left(\mathrm{mg} \mathrm{N} \mathrm{L}^{-1}\right)\end{array}$ & $\begin{array}{r}\text { Emission Factor } \\
\left(\mathrm{EF}_{5 \mathrm{r}}\right)\end{array}$ & $\begin{array}{r}\text { Indirect } \mathbf{N}_{2} \mathbf{O} \\
\text { flux } \\
\left(k^{-1} \mathrm{Nha}^{-1} \mathrm{a}^{-1}\right)\end{array}$ \\
\hline \multirow[t]{3}{*}{ Wensum } & Chalk & Unconfined & 104 & $2.53(0.92)^{\mathrm{a}}$ & $9.21(2.02)^{\mathrm{a}}$ & $0.00030(0.00015)^{\mathrm{a}}$ & $9.75(4.57)^{a}$ \\
\hline & Chalk & Semi-confined & 104 & $1.31(0.40)^{\mathrm{b}}$ & $5.99(1.81)^{\mathrm{b}}$ & $0.00022(0.00008)^{\mathrm{b}}$ & $5.09(2.03)^{\mathrm{b}}$ \\
\hline & Chalk & Confined; glacial deposits & 312 & $0.79(0.26)^{\mathrm{c}}$ & $5.20(2.24)^{\mathrm{c}}$ & $0.00016(0.00014)^{\mathrm{c}}$ & $2.72(1.62)^{\mathrm{c}}$ \\
\hline \multirow[t]{3}{*}{ Eden } & Limestone & Confined; glacial deposits & 21 & $0.52(0.09)^{\mathrm{a}}$ & $8.61(1.33)^{\mathrm{a}}$ & $0.00007(0.00001)^{\mathrm{a}}$ & $1.50(0.64)^{\mathrm{a}}$ \\
\hline & Volcanics & Confined; glacial deposits & 27 & $0.57(0.34)^{\mathrm{a}}$ & 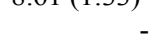 & & $1.72(1.10)^{\mathrm{b}}$ \\
\hline & Sandstone & Confined; glacial deposits & 27 & $0.61(0.44)^{\mathrm{b}}$ & $4.52(5.21)^{\mathrm{a}}$ & $0.00019(0.00010)^{\mathrm{b}}$ & $2.19(1.84)^{\mathrm{b}}$ \\
\hline \multirow[t]{2}{*}{ Avon } & Chalk & Unconfined & 29 & $16.83(12.93)^{\mathrm{a}}$ & $7.01(0.41)^{\mathrm{a}}$ & $0.00235(0.00186)^{\mathrm{a}}$ & $60.14(51.98)^{\mathrm{a}}$ \\
\hline & Mudstone & Unconfined & 27 & $0.69(0.95)^{b}$ & $4.46(2.49)^{\mathrm{b}}$ & $0.00020(0.00057)^{\mathrm{b}}$ & $1.95(8.98)^{b}$ \\
\hline \multirow[t]{4}{*}{ All } & Chalk & Unconfined & 133 & $3.03(9.14)^{\mathrm{a}}$ & $8.51(2.02)^{\mathrm{a}}$ & $0.00036(0.00134)^{\mathrm{a}}$ & $10.83(33.70)^{\mathrm{a}}$ \\
\hline & Chalk & Semi-confined & 104 & $1.31(0.40)^{\mathrm{b}}$ & $5.99(1.81)^{\mathrm{c}}$ & $0.00022(0.00008)^{\mathrm{b}}$ & $5.09(2.03)^{\mathrm{b}}$ \\
\hline & Mudstone & Unconfined & 27 & $0.69(0.95)^{\mathrm{bc}}$ & $4.46(2.49)^{\mathrm{b}}$ & $0.00020(0.00056)^{\mathrm{a}}$ & $1.95(8.98)^{\mathrm{bc}}$ \\
\hline & Various* & Confined; glacial deposits & 387 & $0.76(0.28)^{\mathrm{c}}$ & $5.26(2.65)^{\mathrm{d}}$ & $0.00016(0.00014)^{\mathrm{c}}$ & $2.58(4.62)^{\mathrm{c}}$ \\
\hline
\end{tabular}

* includes limestone, chalk, sandstone and volcanic bedrock

569

570 Table 2: Seasonal variability in nitrogen dynamics for sites with contrasting hydrogeological types in the River

571 Wensum catchment. Values presented as medians with one standard deviation in parentheses. Different

572 superscript letters denote significant differences $(t$-test $p<0.05)$ between seasons with the same hydrogeological

573 type.

\begin{tabular}{|c|c|c|c|c|c|c|}
\hline Hydrogeological type & N samples & Parameter & Spring (MAM) & Summer (JJA) & Autumn (SON) & Winter (DJF) \\
\hline Unconfined Chalk & 104 & $\begin{array}{l}\mathrm{N}_{2} \mathrm{O}\left(\mu \mathrm{g} \mathrm{N} \mathrm{L}^{-1}\right) \\
\mathrm{NO}_{3}^{-}\left(\mathrm{mg} \mathrm{N} \mathrm{L}^{-1}\right) \\
\mathrm{EF}_{5 \mathrm{r}} \\
\text { Flux }\left(\mathrm{kg} \mathrm{N} \mathrm{ha}^{-1} \mathrm{a}^{-1}\right)\end{array}$ & $\begin{array}{r}2.07(0.90)^{\mathrm{a}} \\
9.70(1.44)^{\mathrm{a}} \\
0.00021(0.00010)^{\mathrm{a}} \\
8.14(5.11)^{\mathrm{ab}}\end{array}$ & $\begin{array}{r}3.06(0.83)^{\mathrm{b}} \\
8.22(1.10)^{\mathrm{b}} \\
0.00039(0.00011)^{\mathrm{b}} \\
9.06(2.90)^{\mathrm{b}}\end{array}$ & $\begin{array}{r}3.21(0.93)^{\mathrm{b}} \\
8.72(2.64)^{\mathrm{ab}} \\
0.00039(0.00020)^{\mathrm{b}} \\
10.40(3.84)^{\mathrm{ab}}\end{array}$ & $\begin{array}{r}2.47(0.81)^{\mathrm{ab}} \\
10.00(2.12)^{\mathrm{a}} \\
0.00027(0.00009)^{\mathrm{a}} \\
11.82(5.15)^{\mathrm{a}}\end{array}$ \\
\hline Semi-confined Chalk & 104 & $\begin{array}{l}\mathrm{N}_{2} \mathrm{O}\left(\mu \mathrm{g} \mathrm{N} \mathrm{L}^{-1}\right) \\
\mathrm{NO}_{3}^{-}\left(\mathrm{mg} \mathrm{N} \mathrm{L}^{-1}\right) \\
\mathrm{EF}_{5 \mathrm{r}} \\
\text { Flux }\left(\mathrm{kg} \mathrm{N} \mathrm{ha}^{-1} \mathrm{a}^{-1}\right)\end{array}$ & $\begin{array}{r}1.10(0.36)^{\mathrm{a}} \\
6.68(1.90)^{\mathrm{a}} \\
0.00019(0.00005)^{\mathrm{a}} \\
5.21(2.07)^{\mathrm{a}}\end{array}$ & $\begin{array}{r}1.42(0.37)^{\mathrm{b}} \\
4.60(1.62)^{\mathrm{b}} \\
0.00030(0.00009)^{\mathrm{b}} \\
4.19(1.61)^{\mathrm{b}}\end{array}$ & $\begin{array}{r}1.39(0.45)^{\mathrm{b}} \\
5.90(1.41)^{\mathrm{a}} \\
0.00025(0.00005)^{\mathrm{c}} \\
4.31(1.99)^{\mathrm{ab}}\end{array}$ & $\begin{array}{r}1.26(0.38)^{\mathrm{ab}} \\
6.71(1.84)^{\mathrm{a}} \\
0.00020(0.00006)^{\mathrm{a}} \\
5.89(2.00)^{\mathrm{c}}\end{array}$ \\
\hline Confined Chalk & 312 & $\begin{array}{l}\mathrm{N}_{2} \mathrm{O}\left(\mu \mathrm{g} \mathrm{N} \mathrm{L}^{-1}\right) \\
\mathrm{NO}_{3}^{-}\left(\mathrm{mg} \mathrm{N} \mathrm{L}^{-1}\right) \\
\mathrm{EF}_{5 \mathrm{r}} \\
\text { Flux }\left(\mathrm{kg} \mathrm{N} \mathrm{ha}^{-1} \mathrm{a}^{-1}\right)\end{array}$ & $\begin{array}{r}0.75(0.24)^{\mathrm{a}} \\
5.81(1.90)^{\mathrm{a}} \\
0.00015(0.00006)^{\mathrm{a}} \\
2.81(1.46)^{\mathrm{a}}\end{array}$ & $\begin{array}{r}0.74(0.26)^{\mathrm{a}} \\
4.31(2.27)^{\mathrm{b}} \\
0.00019(0.00024)^{\mathrm{b}} \\
2.01(1.02)^{\mathrm{b}}\end{array}$ & $\begin{array}{r}0.79(0.24)^{\mathrm{a}} \\
4.72(2.39)^{\mathrm{b}} \\
0.00016(0.00013)^{\mathrm{bc}} \\
2.48(0.89)^{\mathrm{c}}\end{array}$ & $\begin{array}{r}0.87(0.29)^{\mathrm{b}} \\
5.59(2.21)^{\mathrm{a}} \\
0.00016(0.00008)^{\mathrm{c}} \\
3.94(1.93)^{\mathrm{d}}\end{array}$ \\
\hline
\end{tabular}




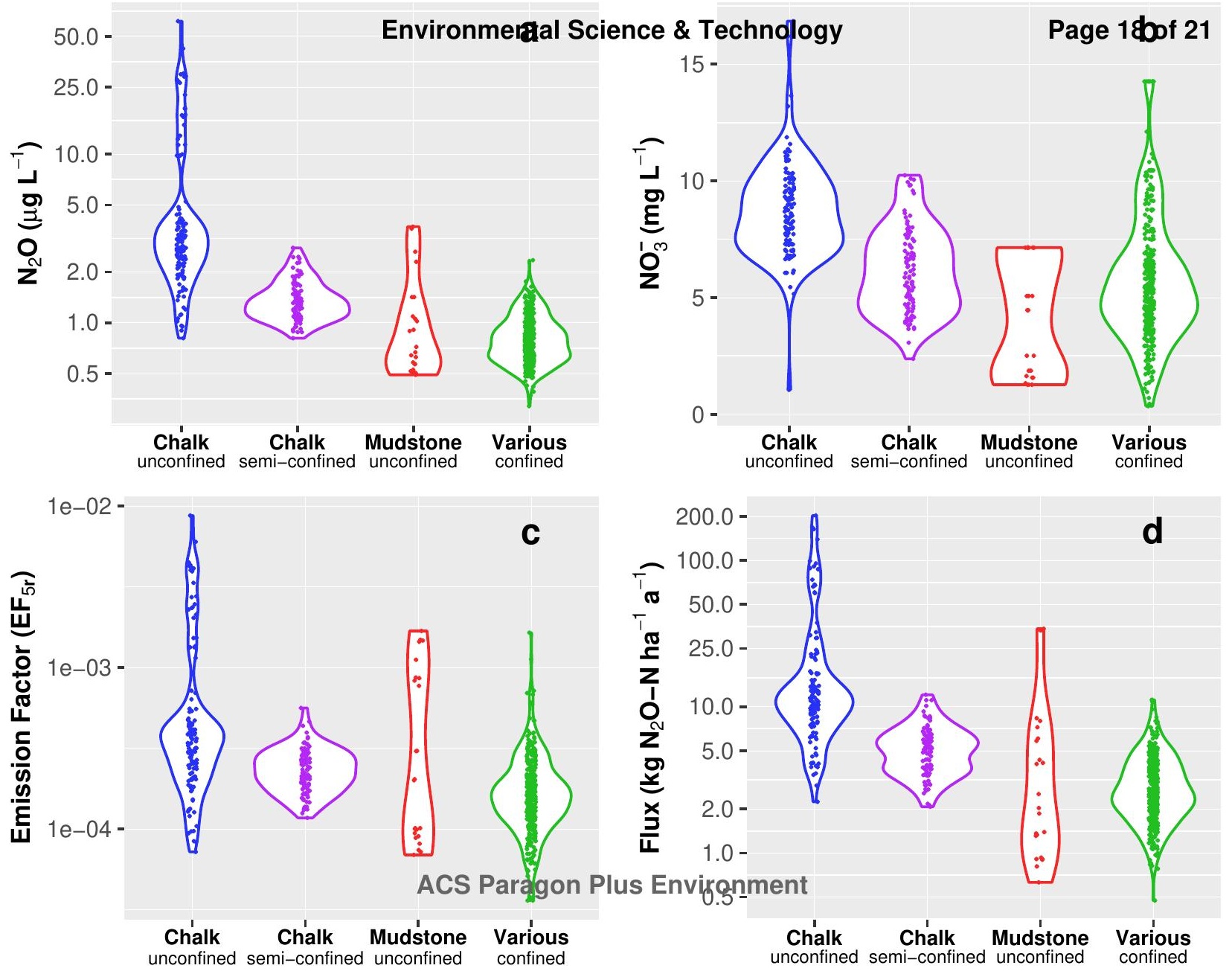




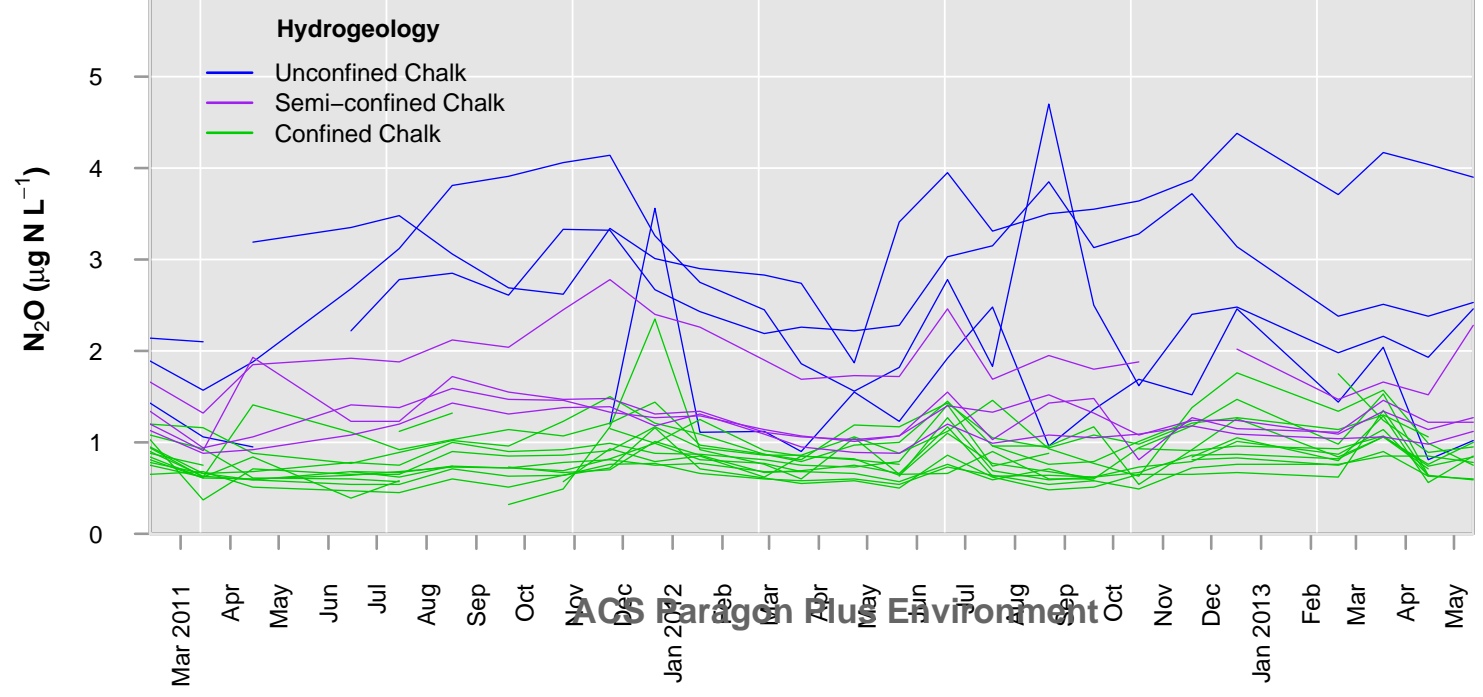




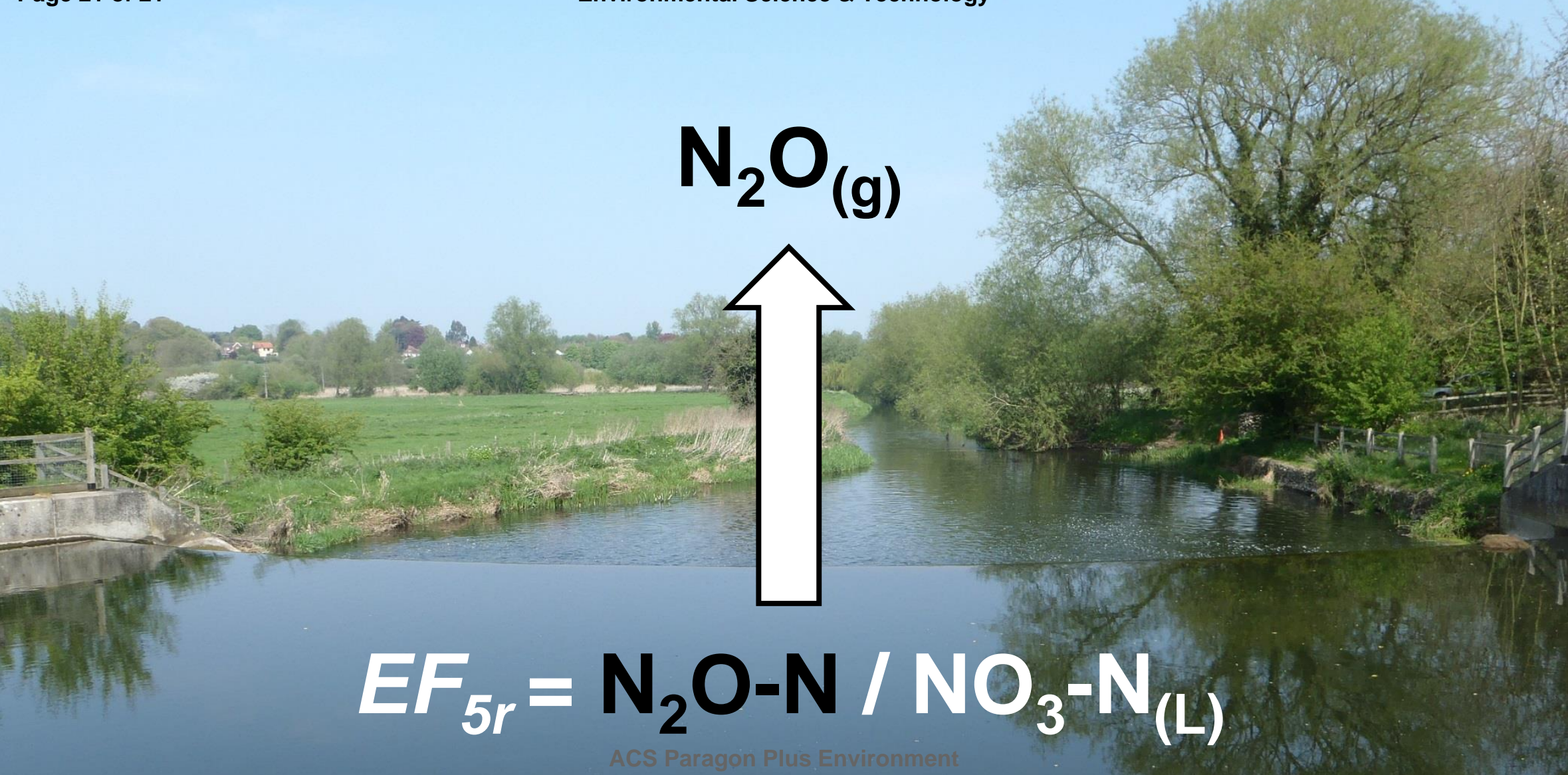

River Wensum, UK 